Article

\title{
Creating Green Space Sustainability through Low-Budget and Upcycling Strategies
}

\author{
Krzysztof Herman $^{1}$ (iD), Madalina Sbarcea ${ }^{2,3}$ (D) and Thomas Panagopoulos ${ }^{4, * \text { (D) }}$ \\ 1 Department of Landscape Art, Warsaw University of Life Sciences, 02-787 Warsaw, Poland; \\ krzysztof_herman@sggw.pl \\ 2 Danube Delta National Institute for Research and Development, 820112 Tulcea, Romania; \\ madalina.sbarcea@ddni.ro \\ 3 Ion Mincu University of Architecture and Urbanism, 010014 Bucharest, Romania \\ 4 Research Centre of Tourism Sustainability and Well-being, University of Algarve, 8005-139 Faro, Portugal \\ * Correspondence: tpanago@ualg.pt; Tel.: +351-289-800-900
}

Received: 14 April 2018; Accepted: 29 May 2018; Published: 3 June 2018

check for updates

\begin{abstract}
Frugality is a core notion of sustainability, and responsible resource management should be prioritized in urban planning and landscape architecture. Low-budget strategies as a deliberate means of creating valuable, attractive, well-used, sociable public spaces are recognized by some influential designers using the "Light, cheap, quick" methodology. Unused spaces, just like objects and waste, can be creatively changed, reinvented with little resource input through a circular solution of upcycling. Case study methodology was predominantly used in the inquiry with three new parks, built after the year 2004, in Faro, Portugal. The study examined how the success rate and the current state of these public green areas correlates with the amount of financial resources invested in each of the projects. The case studies show key aspects in the building of the three spaces including: urban context, management and community participation. The success rate of a place is established based on user activity observations, user counts and questionnaires - conveyed amongst both experts and local residents. Results illustrate how low-budget strategies and limited use of funds and resources can be translated into a successful project of a public greenery. Comparative studies from Warsaw and Berlin further extend the discussion to the concept of upcycling as a sustainable solution for landscape architecture.
\end{abstract}

Keywords: design; low-budget strategies; public green space; upcycling; frugality; landscape architecture; sustainable development

\section{Introduction}

Urban nature and green infrastructure support sustainable development of cities [1]. Green infrastructure can be defined as a network of natural and semi-natural spaces, which provides additional interconnection and enhanced resilience benefits [2]. The Millennium Ecosystem Assessment [3] has divided ecosystem services into four groups relevant to well-being: regulating services, cultural services, support services and provisioning services.

While there is much to gain with the abundance of green spaces in the city, the social and psychological benefits are considered the most sought after [4]. By providing resources as a place for relaxation and recreation, green spaces play a great role in increasing the quality of urban areas and promoting healthy lifestyles [1]. Urban green spaces provide immediate access to the "experience of nature" that comes with various aspects and elements of landscape. Trees and other vegetation, animals, wind and flowing water, and changes of seasons positively affect human health and well-being [4-7] Quantity and quality of green spaces situated in the vicinity of urban settlements associates positively 
with perceived mental health [8-10]. To fulfil this premise, green spaces have to not only be well designed, with the focus on natural habitats, wildlife and resilient technologies, but also be well used and appreciated by the public.

Social participation and understanding of the local community must play an important role in the sustainable development of a place [11-13]. It has become common knowledge in professional circles that the involvement of various stakeholders, citizen groups and large number of urban dwellers in the design process leads to more socially sustainable projects that are well-rooted in the community [14-16]. Engagement and empowerment of the residents creates a sense of responsibility for place transforming a simple "user" of a green space into a "host", "caretaker", "facilitator", etc. Collective community-based effort is also at the root of many low budget urban approaches and solutions [17]. Researchers in various fields see the reality of the post-crisis economy influenced by new notions and ways to reorganize the city differently-through grassroots, local, autonomous, and resource efficient frameworks $[18,19]$. Through community gardening, car sharing, co-working, food cooperatives and waste recycling, urban dwellers develop innovative, alternative or entrepreneurial ways to challenge resource-heavy ways of managing, developing and living in the city [20,21]. While frugality is often seen in everyday amateur practices [22] (DIY, home alteration, gardening, etc.), municipalities, governments and officials tend to be less focused on the amount of resources that are being used in the process of creation of a new green space.

Low-budget and intervention-based approaches have only recently been seen as an emerging trend in the practice of landscape architecture [23] and urban design. Among several low-budget strategies, perhaps the most recognition is given to the LQC (Light Quick Cheap) tool developed and popularized by New York based office Project for Public Spaces [24]. The tool that involves creating temporary and relatively inexpensive alterations to a public space serves as a part of more complex approach-placemaking. LQC is about contesting "design-heavy, multi-million dollar projects" by appreciating the fact that "sometimes the most exciting spaces are low-key, low-cost, and in the most unexpected locations" [24].

Thriftiness should be prioritized not only due to budget restrictions but also as an important notion of a larger narrative that embraces fixing, reusing and incorporating elements of previous infrastructure or landscape. Much can be taken from the frugal architecture of slums-which, out of necessity rather than out of choice, have been created with a great awareness for resource limitations. Recycling of building materials, optimization in the use of limited, available space, community integration and participation as well as the dynamism, flexibility of settlements and space has made architects to look towards slums for sustainable ideas [25]. In addition to the resource consciousness, the sustainable approach calls for transformation of previously developed areas which are currently abandoned or underused [26]. Redevelopment of brownfield land is regarded as an essential component of the achievement of a sustainable urban regeneration [27-29].

Ziehl and Oßwald [30] discussed possible scenarios for adaptation of buildings and brownfields with the use of the term "second hand spaces". This concept emphasizes the sustainable effects of temporary uses on urban development underlining "alternative practices like sharing, do-it-yourself, collective self-organization, try-outs, recycling and flexible operation". Through low-budget interventions, temporary use, programming and prototyping such spaces could not only be reclaimed and regenerated, but also upcycled—creatively reinvented with minimal use of resources. Such process-oriented methodology in planning and design can bring large advantages in comparison to a rigidly oriented perception, giving more space for creativity and unusual solutions [31].

Taken from industrial design and waste management, the term upcycling describes an approach in which waste materials are converted into something of higher quality or value in a second life [32,33]. It is regarded as one of the most sustainable circular solutions, positioned between reuse and recycling. Upcycling typically requires little energy and resource input and can eliminate the need for a new product [33]. Upcycling as a tool for sustainability and solution in the age of resource scarcity is 
strongly connected to design practices [34]. Landscape architecture should support the transition from a linear to a circular economy by making reuse more visible as a scope for sustainable cities [35].

The objective of this article is to explore the notions of low-budget approach and resource effectiveness as a means for the creation of green spaces. The hypothesis of this study is that "financial and material resources, professional and technical training do not ensure nor provide for a successful, appreciated urban green space". The overall aim of the study was to investigate how three public recreational spaces are successful and appreciated as perceived by two user groups: experts and common citizens, and addressed the following two research questions: Is the success rate of a green space dependent on the amount of initial investment? Can low-budget strategies be as effective as resource-heavy designs in creating valuable green infrastructure?

\section{Materials and Methods}

\subsection{Case Studies}

Case study as a key research method for urban design, planning and landscape architecture has been advocated for decades. It has a great potential to advance research, practice and education in the field [36-38]. One of its main propagators, Mark Francis, suggests three formats for case study: abstract case study, full case study and in-depth analysis [37]. The first format, which contains very brief descriptions of project background, significance, impact and outcomes is perhaps the most suitable for a problem oriented investigation (issue typology). Then, this study used short, abstract case studies as the main part of research, presenting three comparative cases from one city and two reference cases showcasing external examples that complement the inquiry. These references aimed to present projects that, on different scales, use low-budget strategies as a conscious, core aspect of creating green spaces that are appreciated by the public. Two international cases gave the research a broader, Europe-wide outlook and served as an example of possible contexts in which low-budget strategies can be applied, also providing evidence of such practices being tested or (often spontaneously) employed in other urban environments.

The primary area for the case studies is the city of Faro (approximately 65,000 inhabitants), located in southern Portugal. Faro has a moderate Mediterranean climate with warm and sunny summers with average daytime temperatures of $35^{\circ} \mathrm{C}$ and an annual rainfall of around $350 \mathrm{~mm}$ [39]. It is the capital of the Algarve region, which bases its economy on tourism. The city is surrounded to the north by an agricultural countryside and to the south by the Ria Formosa National Park, a protected wetland and sand dune islands that play an important role in the region's economy.

Green Infrastructure has recently gained importance as a planning tool in Portugal, at the regional and local levels due to the provision of ecosystem services and positive contribution to human health and well-being [40], and it can be the base for climate change adaptation [41]. According to Loures et al. [42], the rapid growth of Algarve cities creates challenges and urban parks play an important role in sustainable city development. The demographic challenge was another important factor to find the appropriate policies to maintain the city attractiveness and residential satisfaction [43-45]. The city of Faro almost doubled its population the last three decades but without subsequent investment in green infrastructure, which is now as low as $8 \mathrm{~m}^{2} /$ resident [39].

In a time of fiscal austerity, cost-effectiveness had become critical. As a result, the city authorities were interested in identifying cost-effective alternatives to tackle challenges arising from biodiversity loss, climate change, more frequent natural disasters and rapid urbanization. This article provides abstract case studies for the three parks in Faro built after the year 2000. All of them were conceived as primarily recreational and activity spaces for the citizens of Faro. Although different in scale and form, their construction was related to the need for new parks in an area of intensified development, both previously built and planned. 


\subsection{Survey}

According to Berte et al. [45], there are four major drivers to be considered in design: identity process, integration process, multiscale process, and innovation process. Even though there are direct and indirect methods for landscape evaluation [46], the most common and effective way to evaluate the success of a landscape project is with a survey of the views and perceptions of experts and users [47-49]. Expert survey method is usually employed in cases where several professionals possess knowledge or can make assessments that are not available in the public domain [50]. It is broadly used in social and political sciences and has been successfully applied in sustainability and design research [48]. In general, the method implies rather small sample sizes and similar preliminary expert surveys have been conducted with group of $n=20$ responders [51]. The methodological steps of the study are described in Table 1.

Table 1. Methodological steps for the survey.

\begin{tabular}{|c|c|c|c|}
\hline Stage & Criteria & Result & Comments \\
\hline Choice of sites & $\begin{array}{c}\text { Urban recreational green spaces built after year } 2004 \\
\text { in Faro region }\end{array}$ & $\begin{array}{c}3 \text { sites: } \\
\text { Parque das Cidades } \\
\text { Parque Ribeirinho } \\
\text { Parque de Lazer }\end{array}$ & $\begin{array}{c}\text { The } 3 \text { parks vary in scale but were } \\
\text { created to provide recreational } \\
\text { green space }\end{array}$ \\
\hline Choice of method & $\begin{array}{l}\text { Established methodology using non-probability } \\
\text { sampling (expert/convenience sampling) }\end{array}$ & Expert survey & $\begin{array}{l}\text { Local citizens act as a second } \\
\text { group of experts (providing local } \\
\text { "participatory" knowledge) }\end{array}$ \\
\hline Recruitment of surveyees & $\begin{array}{l}\text { (a) local landscape architects and urban planners } \\
\text { (b) local citizens, park users }\end{array}$ & $\begin{array}{l}2 \text { groups of surveyees, both } n=10 \\
\text { (total } n=20)\end{array}$ & $\begin{array}{l}\text { Group b was randomly recruited } \\
\text { in public spaces of Faro }\end{array}$ \\
\hline Statistical Analysis & $\begin{array}{l}\text { Non-parametric testing to find statistically } \\
\text { significant differences in paired samples }\end{array}$ & As shown in results chapter 3.6 & $\begin{array}{l}\text { Only one of the two samples } \\
\text { ("local residents" group) was } \\
\text { returning a normal distribution }\end{array}$ \\
\hline
\end{tabular}

The group for the preliminary expert survey was appointed from the faculty members at the University of Algarve in Faro $(n=10)$ and local citizens $(n=10)$. The first group consisted of professionals in the fields of urban planning and landscape architecture, and the second of active local residents of the area and users of the three green spaces. The group of local citizens was recruited in public spaces in and around the University of Algarve campus, which is located an equal distance from all three parks $(5 \mathrm{~km})$ through a randomized selection process (every third person was approached). The interviews were always conducted by the same researcher, ensuring that the interviewee has "participatory knowledge" of all three places-lives in the vicinity and has at least once been and used each of the green spaces. Active local residents in participatory processes are often included as expert voice and seen as important source for knowledge of the place [52-54].

The study was carried out using face-to-face interviews in the city of Faro during 2017 by means of a five-point Likert-scaled questions. The goal of the survey was to establish the perceived success rate of the three parks (P. de Lazer, P. Riberinho, and P. Das Cidades) as seen by both the professionals and the local residents. Questions (impacts) in the appointed questionnaire were taken from the list of suggested impacts that should be considered in monitoring and evaluation of urban green spaces created by the World Health Organization, Regional Office for Europe (WHO) [55]. It consisted of 14 questions grouped into four thematic areas: environmental/ecological impacts, lifestyle impacts, social impacts and equity impacts (Table 2). Interviewees from both groups answered the same questions judging impacts in Likert scale with responses ranking from 1 "not at all influential" to 5 "extremely influential" (except for the question about "Gentrification processes leading to displacement of local residents" where 5 was "doesn't cause gentrification" and 1 was "causes gentrification and leads to displacements"). 
Table 2. Survey on impacts and success rate of the three most recent parks of Faro city.

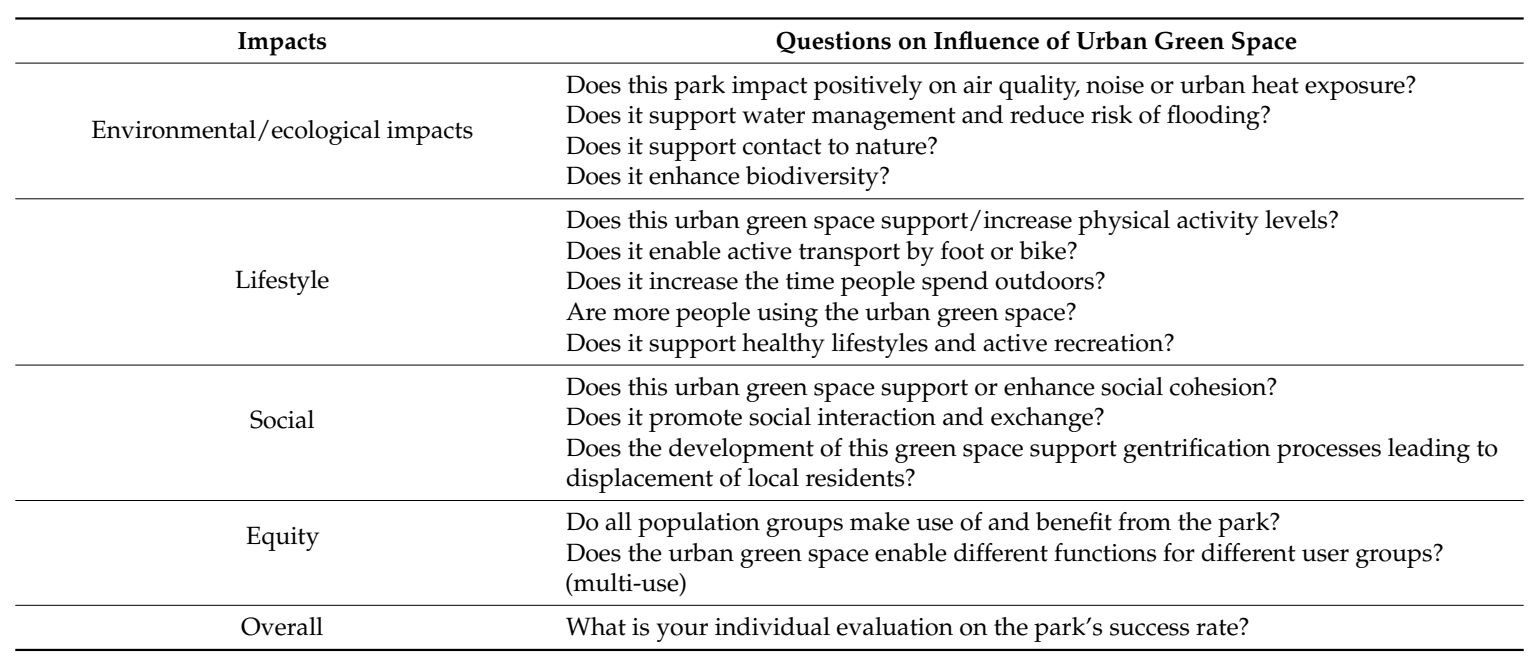

Note: Responses were given in 1-5 scale, where: 1 "not at all influential", 2 "slightly influential", 3 "somewhat influential", 4 "very influential", and 5 "extremely influential" (except gentrification).

Impact aspects ranged from biodiversity and water management to users' physical activity levels and community building. At the end, there was one question added to the WHO list as a general inquiry about the perceived and individual evaluation on the parks success rate ("What is your individual evaluation on the park's success rate?").

Cronbach's $\alpha$ test provided evidence that the components of the scale are sufficiently intercorrelated and that the grouped items measure the underlying variable. The total of 15 questions constituted a multi-theme variable to be tested through reliability and credibility analysis. More specifically, to determine the internal reliability of the questionnaire, Cronbach's $\alpha$ reliability coefficient was 0.70 or higher, which was regarded as satisfactory [56].

\section{Results}

\subsection{Parque de Lazer das Figuras}

Size: 1.5 ha.

Initial investment: 150,000 Euro.

Situated in between the largest shopping mall in the Algarve region (Forum Algarve, opened in 2001), a large residential area and a main street, an entryway to Faro, Parque de Lazer das Figuras has undoubtedly the advantage of a good, accessible location. Perhaps this is why in the early 2000s a plan was in place to build a gas station on this particular empty lot. In 2005, this plan fell apart as the court did not recognize the "public interest" in the transfer of rights to the municipal land for such development. In the following years, the Mayor of Faro announced that 150,000 euro would be secured for the construction of a green space that would "provide the population with more physical exercise and recreational activity" and since 2011 the space of 1.5 ha has been gradually developed. The park is arranged in a minimalistic way with a large $(0.85 \mathrm{ha})$ central open field of which 0.15 ha is taken by a wide concrete strip and 0.7 ha by a lawn (Figure 1a). The rest of the space is arranged peripherally with places of activity: playground; small, fenced football field; tennis court; and pocket-sized outdoor gym. The southern edge of the park is dedicated for a small-scale building that hosts a pizzeria (Figure 1b). Parque de Lazer (Portuguese for "Leisure Park") continues to be developed with the help of some recurring local initiatives. 


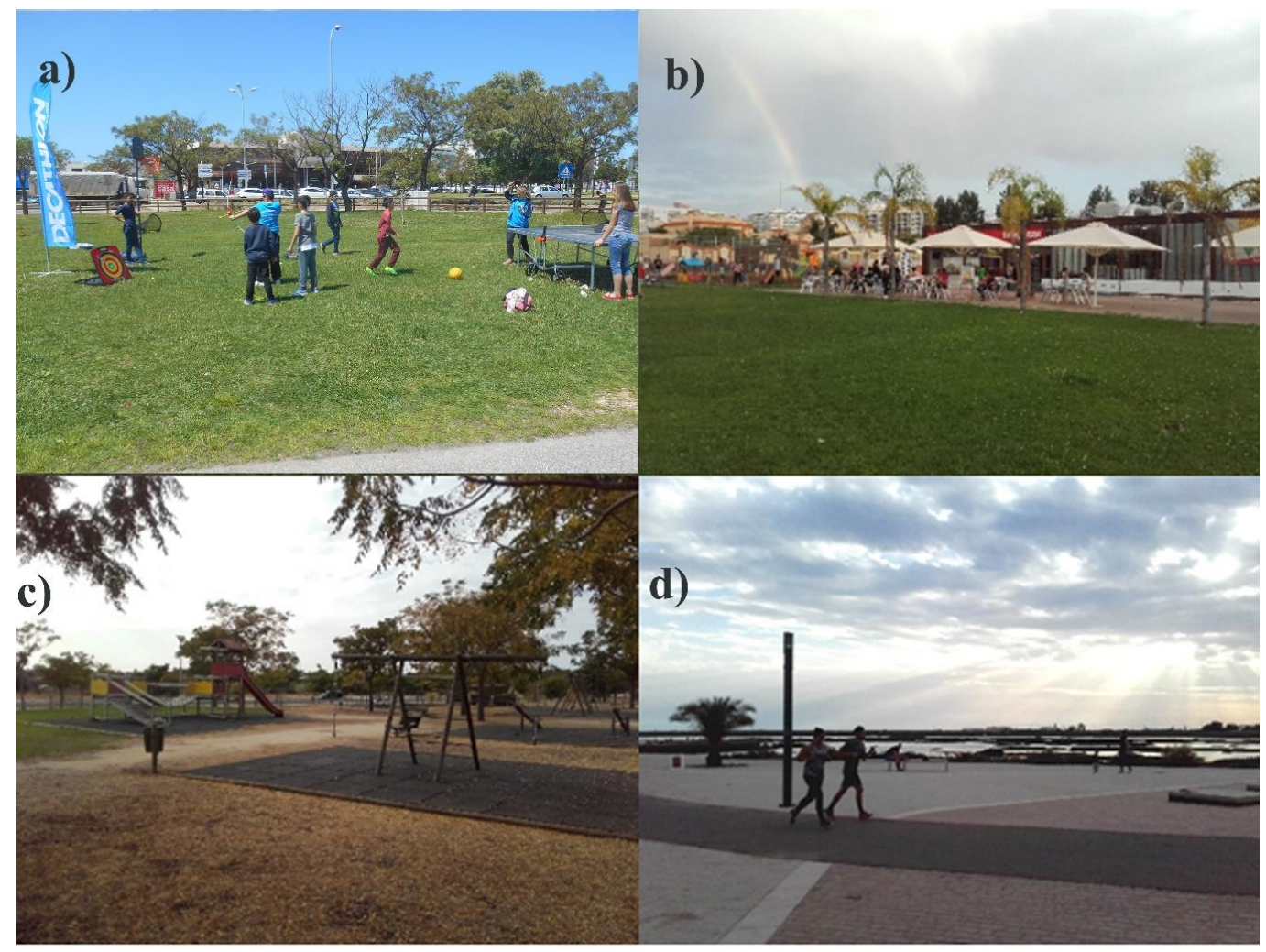

Figure 1. Parque de Lazer das Figuras (a,b); Parque das Cidades (c); and Parque Ribeirinho de Faro (d) (K. Herman photo-all rights reserved).

In 2016, the users of the park planted several young trees that will in the future add much needed shade and also procured an additional 30,000 euro funding for the construction of a wooden fence around the open space, benches and a handful of smaller alterations. The park has been, for several years now, effectively programmed with numerous events organized through the Active Faro program-an initiative of the municipality that promotes amateur sports and recreation. As a result, Parque de Lazer has hosted demonstrations and training sessions of Aikido, handball, basketball, boxing, Capoeira, dances, soccer, gymnastics, Karate, kickboxing, rugby, functional training, horseback riding, chess, yoga, Zumba and many more. For each use, this versatile and accessible space has been slightly altered, transformed by the users and the transitory, interim function. It is a simple, unobtrusive green space that is not only well-used with day-to-day activities but is also very flexible and can host an array of occasional events.

\subsection{Parque Ribeirinho de Faro}

Size: 16 ha.

Initial investment: 3,500,000 Euro.

Parque Ribeirinho (River Park) of Faro is the newest green space in the municipality; designed in 2011, it had its first phase completed and opened in 2014. The Park is located in a peripheral but intensively developing part of the city, overlooking Ria Formosa Natural Park and former salt evaporation ponds. It is a visibly planned and designed space with various functional zones (entrance area, waterfront, recreational spaces, and parking lots) and elements such as the amphitheater, playgrounds, educational games, etc. It has a clear composition and well-drawn paths and roads.

Green spaces are interspersed with large areas of paved, non-permeable surfaces. Even though the area seems to be well equipped, it lacks constructions that would provide much-needed shade (while trees are still young) and, although it is a new and in first stage development (as of October 2017), 
it is already poorly maintained with an exposed, chaotic irrigation systems as one of the main issues. This recreational waterfront space is separated from the city by train tracks and is poorly linked with the rest of the urban fabric (so far, the connection is limited to one entrance that leads through boom barriers). Most users go there by car to enjoy a quiet jog or a fitness drill while viewing the sunset over the wetlands. It is a moderately popular place for evening activities and gatherings, providing more than enough space for the number of users (Figure 1d).

\subsection{Parque das Cidades}

Size: 225 ha.

Initial investment: 7,900,000 euro for park and parking areas (the total cost of investment was $78 \mathrm{~m}$ euro including $50 \mathrm{~m}$ for the Algarve Football Stadium).

Parque das Cidades (Park of Cities) was built around the Algarve Stadium for the 2004 European Football Championship in similar distances from Loule and Faro urban centers $(10 \mathrm{~km})$. The park was the first new green space built in the region of Faro since the nineteenth century. It was planned as a main recreational and event space - an anchor investment that would attract further urbanization to the area, such as the central regional hospital, shopping malls, offices, and hotels as well as congress and sport (training) centers. Fourteen years later, few of those plans have come to fruition.

Parque das Cidades complex is located $1.5 \mathrm{~km}$, a $20 \mathrm{~min}$ walk, from the train station (9 min train ride from Faro and Loule). The park itself is rather car-friendly, with wide four-lane roads and large roundabouts. A single bike path that runs along one of the main roads through the park fails to connect to any wider system, ending at the entrance to the waste treatment plant and a parking lot. The park provides extensive areas of landscaped parking lots, access roads and large, paved sites for future development. The majority of the green space is arranged as a naturalistic park, a free composition, created in a slightly hilly landscape. Parque das Cidades includes 0.5 ha recreational area with a playground (Figure 1c), small outbuilding, simple wooden gazebos and an outdoor basketball court as well as a full-sized football training ground. In the late summer of 2017, all of the described areas and equipment were in a very poor technical condition-and as field observations have shown-completely unused.

Both municipalities (through the Association of Algarve Municipalities (AMLF)) were involved in the investment of around 78 million euro (including all amenities, parking lots and the green space) with the Stadium as the largest part (50 million euro) [57]. The total cost, not including management and maintenance, was at least $34 \%$ higher than initially anticipated. As a result of the co-owned stadium construction, an administrative division between both municipalities was ordered by the parliament. The division line is marked through the middle of the pitch. The stadium and its surrounding park and recreational areas form a peri-urban complex that has failed to attract public interest outside of sporadic, mass events. Moreover, the investment is highly controversial from a financial point of view, leaving both municipalities with large debts and failing to provide economical sustainability due to high maintenance costs and low revenues.

An attempt at a consensus (geographical and political) between two municipalities, of a total of 135,000 inhabitants, has led to the creation of a City Park that is neither an urban recreational space nor a successful professional sport center. It is a neglected space filled with infrastructure that has consumed a considerable amount of resources and become irrelevant or scarcely used. The results of the observations confirm concerns about the park expressed in the report created by the Portuguese Court of Audits-high initial investment and consequent maintenance costs led to lack of interest from potential users. Poor planning, disconnection from the urban fabric, lack of identification of local needs and absence of participatory approach added to the project's failure.

\subsection{Tempelhofer Feld (Berlin, Germany)—Reference Case Study}

Size: 323 ha including former airport buildings.

Initial investment: 
After closing in 2008, the vast area of former Berlin-Tempelhof airport became spontaneously used as a park. In the early stages, the space was "squatted" by unbidden users who took over parts of the large runway and green fields for activities such as picnics, barbecuing, gardening, sports (running, roller-skating, biking, street windsurfing, etc.), bird watching and others. It has become the largest recreational park in the city, even though it was not legally sanctioned or officially approved. The park quickly grew very popular amongst young Berliners who looked for a place that offered freedom, openness and potential for creativity. The park is no more than a strip of flat land with a large meadow and very few trees that offers panoramic vistas and a wide unobstructed view onto the horizon, which is rare and valuable in the urban landscape.

In 2010 the former airport was bought by the city and formally recognized as a city park, with its own budget for investment (€60 million for years 2010-2017). Meanwhile, the city began working on a masterplan that included a new business center, office buildings, housing estates and a still large but considerably smaller central green space. One of the aims was to host a large exhibition (International Garden Exhibition (IGA)) on the Tempelhofer grounds.

These plans were opposed by the activist group "100\% Tempelhofer Feld" who advocated lack of trust towards the local government and developers, arguing that the park was best left as it was. They forced a local referendum (held in 2014) in which, with $64.3 \%$ votes, citizens decided to affirm the results of interim land use, accepting the current state and the bottom-up development. Community gardens, racing tracks on the runways, protected areas for rare bird nesting, temporary bars and small-scale makeshift architecture became legal and welcomed. In 2017, Tempelhofer Feld was seen as one of the best examples of truly democratic, participatory public spaces in the world. Architect Martin Rein-Cano claims that it is one of the best parks in the world and that no landscape architect could better design a space for such an array of activities and an open place that makes everybody feel like they are welcomed and can do something for themselves [58]. These low-budget, spontaneous and informal arrangements are recognized as distinctive for the process which became a valid strategy for the Tempelhofer Feld Park (Figure 2).

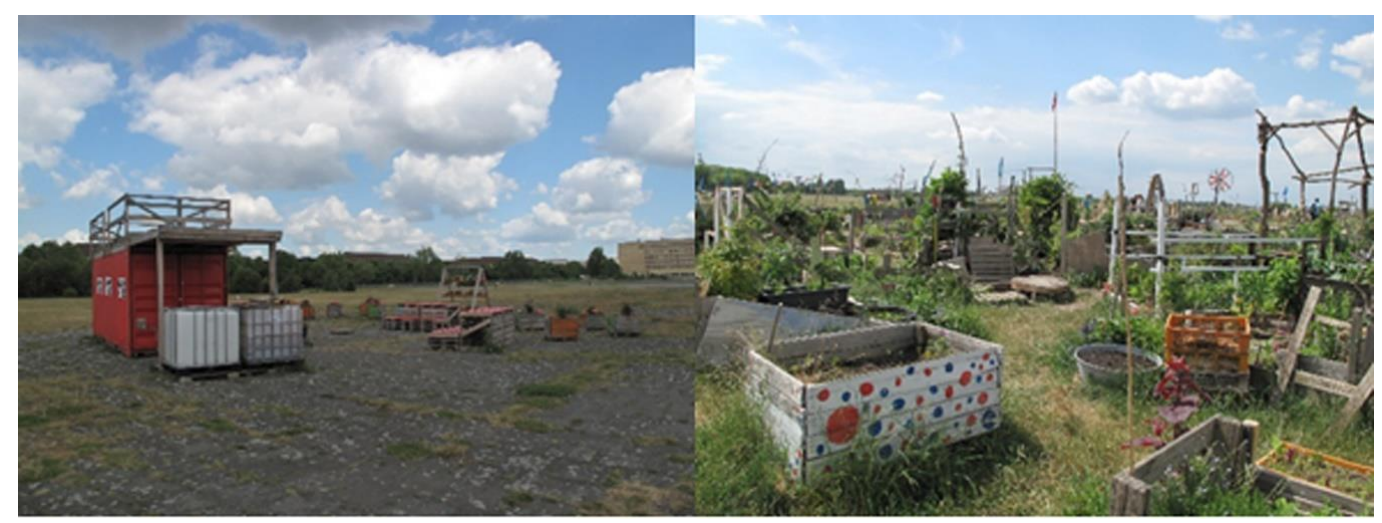

Figure 2. Low-budget solutions for public bar/cafe and community garden at the Tempelhofer Feld (K. Herman photo-all rights reserved).

\subsection{Górka Archipelago (Warsaw, Poland)—Reference Case Study}

Size: 0.8 ha.

Initial investment: 13,000 Euro (LQC prototyping), 150,000 euro (permanent constructions).

"Górka" ("The hill") is the customary, local name for a square between two large apartment buildings and a school in the "Za Żelazna Brama" ("Behind Iron Gate") housing estate in the center of Warsaw. The large buildings constructed in the late sixties host around 1000 inhabitants each. Although the most sizeable public space in the neighborhood, the square remained relatively under-used, considering the large number of residents in the area. 
Górka is mostly tarmacked but has some adult trees and lawns, especially in the northern part that is raised and shaped in a form of a small hill. The "Na Miejscu" ("On site") project that aimed to regenerate and redesign the space started in 2012. The intervention began with several workshops and meetings with local residents, and prototyping of the place (Light-Quick-Cheap interventions).

The first stage of the project (LQC), guided by Project for Public Spaces, added several benches, a single outdoor gym element, football field lines, a small tribune and painted pavement games. Most of the improvements were created with the participation of the local residents. The prototypes and scattered financing possibilities indicated the direction for the stages that followed. A conceptual design "Archipelago" was created-a scenario that was leading to a more permanent change on the square (Figure 3). Every "island" was to be cut out from the tarmac and filled with new elements, objects and functions chosen by the local residents in a democratic process (through voting and deliberations). Over 500 votes were cast that helped to create a new program that aimed to connect the functions of a "public balcony" and a "pristine garden" leading to a greener and more sociable space. The complete idea was presented as a mock-up model and included a financing scheme.

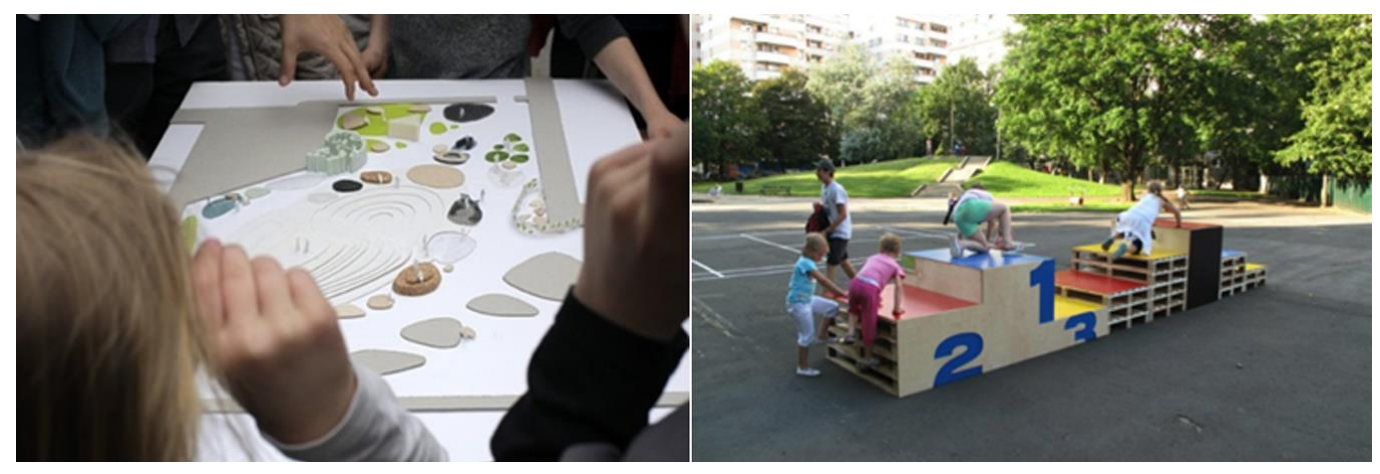

Figure 3. Participatory design process for Górka Archipelago included kids and youth and one of the elements of the LQC prototype design (K. Herman photo-all rights reserved).

The subsequent construction stages (built in years 2014-2017) included: a playground and outdoor gym (municipal funds); raised vegetable beds and living willow dome (funding from the private sector); a lighting and "green" living labyrinth (financed through a participatory budget and local initiative). Several events and improvements were facilitated over time that also left a mark on the area (volunteer fence painting, planting of vines and vegetables). Even though the project is not yet completed, the outcomes are visible and appreciated in the supra-local context-it has been featured on lists of best playgrounds in Warsaw, has been showcased as one of the most successful participatory processes in the city, is a good example of public-private citizen-led partnership and a dispersed financing in small-scale project in urban regeneration.

\subsection{Survey}

The data (900 records of 1- 5 Likert-scaled grades) collected through the survey were statistically analyzed. Only one of the two samples ("local residents" group) returned a normal distribution in Kolmogorov-Smirnov test, therefore we used non-parametric testing (Wilcoxon rank sum tests for paired samples, followed by Bonferroni correction). The results have shown statistically significant differences regarding pairs A (Parque de Lazer) and C (Parque das Cidades) as well as B (Parque Ribeirinho) and C. There is no statistically significant different between samples A and B. Moreover, analysis of the data samples collected from experts and local residents (green space users) have shown that opinions (grades) of both groups were very similar.

Parque de Lazer and Parque Ribeirinho were very closely rated when it comes to the grades obtained through the detailed questions based on the WHO list (Table 3). The grades for Parque das Cidades were significantly lower. When comparing results in four thematic areas, it is visible that 
Parque Ribeirinho was rated high in sustainability impact, and low in social impacts while, in the case of Parque de Lazer, the situation was reversed. Both parks score similarly well within the "lifestyle impact" area. Figure 4 shows that the statistical analysis of the survey result for professionals and local residents indicated similar success rates of P. de Lazer and P. Ribeirinho as compared to the low rate of success of P. de Cidades.

Table 3. Results of the evaluation of urban green spaces survey-arithmetic mean for grades given to three parks in Faro by experts and citizens. Likert scale responses 1-5: "not at all influential" to "extremely influential" (except for the question about "Gentrification processes leading to displacement of local residents" where 5 was "doesn't cause gentrification" and 1 was "causes gentrification and leads to displacements"). Overall mean presents results for the question "What is your individual evaluation on the parks success rate?".

\begin{tabular}{|c|c|c|c|c|c|c|c|c|c|c|}
\hline \multicolumn{2}{|r|}{ Faro parks evaluation } & \multicolumn{3}{|c|}{ Parque de Lazer } & \multicolumn{3}{|c|}{ P. Ribeirinho } & \multicolumn{3}{|c|}{ P. das Cidades } \\
\hline Impact & Factors & Exp. & L.R. & All & Exp. & L.R. & All & Exp. & L.R. & All \\
\hline \multirow{3}{*}{ Environmental } & Air quality and urban heat exposure & 4.0 & 3.2 & 3.6 & 3.8 & 3.5 & 3.7 & 2.6 & 2.3 & 2.5 \\
\hline & Reduced risk of flooding & 3.7 & 3.5 & 3.6 & 3.9 & 4.0 & 4.0 & 3.1 & 3.5 & 3.3 \\
\hline & Biodiversity & 2.9 & 2.8 & 2.9 & 4.5 & 4.2 & 4.4 & 2.6 & 2.9 & 2.8 \\
\hline \multirow{3}{*}{ Lifestyle } & Users' physical activity levels & 4.3 & 3.4 & 3.9 & 4.0 & 3.9 & 4.0 & 2.5 & 2.6 & 2.6 \\
\hline & Active transport by foot or bike & 4.2 & 4.4 & 4.3 & 4.1 & 4.7 & 4.4 & 2.1 & 2.5 & 2.3 \\
\hline & Healthy lifestyle and active recreation & 4.2 & 4.3 & 4.3 & 3.8 & 3.7 & 3.8 & 1.8 & 3.0 & 2.4 \\
\hline \multirow{3}{*}{ Social } & Social cohesion and community building & 4.3 & 4.6 & 4.5 & 3.7 & 3.1 & 3.4 & 1.7 & 2.4 & 2.1 \\
\hline & Social interaction and exchange & 4.5 & 4.2 & 4.4 & 3.0 & 2.1 & 2.6 & 1.5 & 1.6 & 1.6 \\
\hline & Gentrification processes & 4.6 & 3.7 & 4.2 & 3.6 & 3.3 & 3.5 & 3.9 & 3.1 & 3.5 \\
\hline \multirow{2}{*}{ Equity } & Inclusive use of and benefit from the urban park & 4.6 & 4.7 & 4.7 & 4.6 & 4.7 & 4.7 & 2.1 & 2.6 & 2.4 \\
\hline & Enabling multi-use & 4.1 & 4.1 & 4.1 & 4.0 & 3.6 & 3.8 & 2.4 & 2.5 & 2.5 \\
\hline
\end{tabular}

Note: Abbreviations used in the table: P. = Parque (park), Exp. = experts, L.R. = local residents.

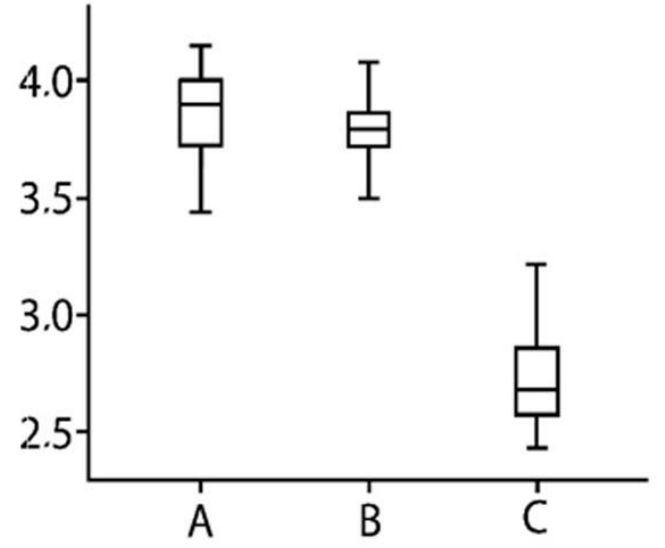

(a)

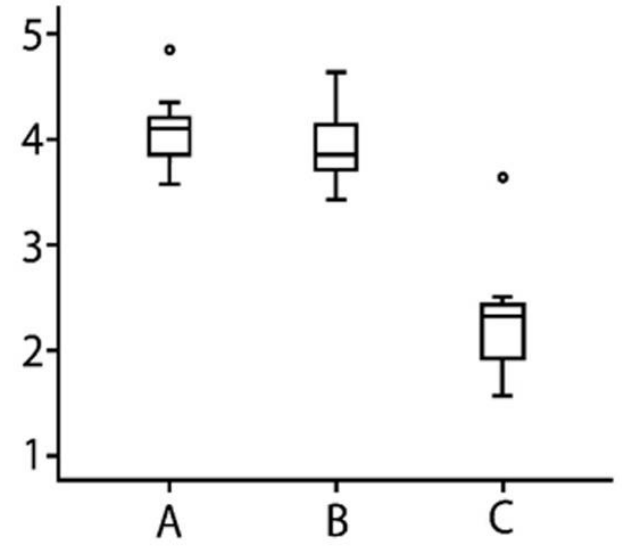

(b)

Figure 4. Box-and-whisker plots of the survey result for: professionals (a); and local residents (b). $A$ is Parque de Lazer; B is Parque Ribeirinho and C is Parque de Cidades. Median values are drawn in the boxes represent the inter-quartile distances, whiskers indicate the range of data with exception of outliners (distance from the edge of the box between 1.5 and 3 times of box length, shown as small circles).

\section{Discussion: Towards the Upcycling of Place}

Quality of city life and the attractiveness of cities are key parameters for success in the global competition for growth. Portuguese cities find themselves in a challenging context facing increasing growth requirements, risks associated with climate change, ageing population, migration, economic pressures and global competition [59]. Key challenges for Sustainable Cities are to provide solutions to 
significantly increase cities' resource efficiency [60]. In times of austerity, more sustainable solutions are needed and Europe has the ambition to be positioned as the world leader in research about solutions that bring more nature and natural features into cities through locally adapted, resource-efficient and systemic interventions [61,62].

Three cases of new parks in Faro, Portugal present three different approaches to the creation of green spaces. Parque de Lazer showcases a bottom-up, low-budget spontaneous path that is based on inclusion and activity programming. It is an urban green space that is well-connected within the urban fabric and in proximity to the potential users-quickly became appreciated and well-used despite its simplicity and frugality. Parque de Lazer attracts a good amount of the city's residents and has become a local hub for amateur sport and leisure activity. With the acceptance of users' sociability of place comes a desire for improvements that are made in a joint effort of the citizens, private investments and the municipality.

Both Parque Ribeirinho and Parque das Cidades are results of top-down processes and professional design practice with much higher rates of initial investments. The first is a successful post-industrial landscape reclamation project and efficiently uses its natural setting of Ria Formosa Nature Reserve to its advantage. The second one was conceived as a result of a national, centralistic effort to host a mass event (Euro Cup) and was created lacking a holistic sustainable approach to urban and landscape planning and without recognition for local needs. Parque das Cidades fails to attract users and is quickly deteriorating, becoming a visible misuse of resources.

The survey results presented Parque de Ribeirinho and Parque de Lazer as almost equally well received parks with the potential to complement each other as far as places of slightly different use. Both citizens and experts value the ecological and landscape impacts of P. Ribeirinho and use it for individual, amateur sport, recreation and family leisure, while P. de Lazer has been successful in attracting larger amounts of younger adults and groups organized around specific (fitness related) events. Location as well as design/form of the two parks largely mirrors the function-paths and singular exercise devices are useful for quiet sunset jogging routines, while the open lawn area and wide tarmacked strip are ideal for spontaneous and planned assemblies.

The two reference case studies present processes that led to successful, appreciated urban green spaces in extreme scales (airport and backyard scale). Both Tempelhofer Feld and Górka Archipelago prove that it is possible to adapt unused or under-used spaces or transform land of a previously different function with very small amounts of resources, through social participation, grassroots activity and rebellious and/or democratic practices.

Through the lenses of upcycling, designers (including landscape architects) could explore ways to create places of greater quality and significance (especially to the local community) while making only the most urgent and necessary changes that would consume minimal amounts of new resources. To achieve this, careful studies of the preexisting strengths of the place, the ways it is used and anticipation of the chances of planned adjustments being accepted or disregarded by the local community have to be undertaken. The conceptual outcome of the design process (going back to the terminology of product design) should be tested and prototyped. Operating in the schemes of public participation, prototyping (through temporary uses and low budget interventions) and upcycling can with certainty lead to projects that use less resources, are devoid of significant errors and provide users with space that fits their needs and is "taylor made".

Upcycled spaces that are planned and programmed in the framework of low-budget design should also be multifunctional-providing local citizens with a variety of ecosystem services. The aim of such a process should be to create synergies that increase the overall benefits provided by the Green Infrastructure [63]. Green infrastructure provides numerous ecosystem services that affect positively people's lives [59]. The success of both Parque de Laser and (in much larger scale) Tempelhofer Feld is due to the seemingly limitless possibilities that these open and easily arrangeable spaces present. Multifunctionality should not be understood as equipping users with many specific and defined functions but rather as supporting possibility and potential for new functions to occur [64]. 
As for the limitations of the study, surveys were conducted on a small sample of experts and citizens. Although methodologically acceptable, the number of interviewees could be (in future research) expanded to provide more diversified group including the non-users of parks and external, non-local experts.

The research focused on a specific locality providing only a limited international context. Due to the focus on green spaces in the Faro region, only 3 parks were compared in the study. A larger number of juxtaposed urban parks that are comparable as far as function and scale would benefit the study. Further studies should explore connections between thriftiness, frugality and low-budget practices and sustainability in the creation and regeneration processes of urban green spaces. New research areas could connect interdisciplinary studies in landscape architecture and existing reports on frugal innovation as a tool for sustainability as well as further the inquiries on upcycling as a low-budget strategy.

\section{Conclusions}

Green spaces created through low-budget strategies can be seen by both the experts and active users as equally successful and valuable to resource-heavy, expensive designs. Three case studies present attempts to create new recreational parks in Faro. One of them (Parque de Lazer) can be seen as very cost-effective the other two have employed standard, top-bottom approach to planning, with rather high initial investments. In a survey conducted on a group of experts and local citizens, Parque de Lazer was rated high as a place that provides social interactions and promotes healthy lifestyles. Overall, it was rated as favorably as a distinctly costlier Parque Ribeirinho (high scores for sustainability) and higher than expensive and excessive Parque das Cidades.

Financial and material resources, professional and technical training do not ensure nor provide for a successful, appreciated urban green space. A place can be turned into a vibrant public green space with very little investment as long as it is tied to participatory planning and collective grassroots efforts. This effort can be both unplanned and spontaneous (Tempelhofer Feld) or initiated by leadersNGO (Górka Archipelago) or municipality/community (Parque de Lazer).

Low-budget strategies can be applied in a testing (prototyping) period leading to a better, well deliberated design as well as become a more permanent but dynamic solution-democratic spaces collectively arranged and programmed within frameworks such as Urban Green Commons [65]. Both situations can lead to a less wasteful use of resources, prioritizing reuse, regeneration and "upcycling" of urban space.

In employing Low-budget strategies, one should look at the existing values of the place not only for inspiration and context for design but also for building materials, social ties, links with urban fabric and existing greenery and biodiversity. Case studies undertaken in this study indicate that, to create a successful sustainable urban green space through low-budget strategies, one should:

1. Prioritize accessible location (identify connections to the urban fabric).

2. Reuse, fix and upcycle (materials, equipment, tools, etc.).

3. Build on social potential (plan participatory processes).

4. Prototype space (trial and test periods for concepts).

5. Create programs (potential for activities created through events rather than through hard infrastructure).

6. Plan for low-cost maintenance (use natural solutions to save water, etc.).

Moreover, the study presents methods for monitoring success rates of green spaces through comparative case studies and expert/citizen surveys. Together with responsible and resource efficient planning, such monitoring techniques can lead to more sustainable and appreciated urban green spaces in the future.

Author Contributions: K.H. and T.P. designed the research and performed the analysis. K.H. and M.S. made the final revision of the paper and answered the reviews questions. 
Funding: This research was funded by Horizon 2020, European Cooperation in Science and Technology, COST Action RESTORE CA16114.

Acknowledgments: This article was conducted within the COST Action CA16114 "Rethinking sustainability towards a regenerative economy" (RESTORE), supported by COST (European Cooperation in Science and Technology). Part of the work was carried out during a Short-Term Scientific Mission of Krzysztof Herman, Poland, to Thomas Panagopoulos, Portugal. The Authors would like to thank prof. Axel Schwerk (Warsaw University of Life Sciences) for consultations regarding statistical analysis and Angela Herman-Childs for the English language editing.

Conflicts of Interest: The authors declare no conflict of interest.

\section{References}

1. Chiesura, A. The role of urban parks for the sustainable city. Landsc. Urb. Plan. 2004, 68, 129-138. [CrossRef]

2. European Environment Agency. Green Infrastructure and Territorial Cohesion. The Concept of Green Infrastructure and Its Integration into Policies Using Monitoring Systems; Publications Office of the European Union: Luxembourg, 2011.

3. Millenniun Ecosystem Assessment. Ecosystems and Human Well-Being: Current State and Trends; Island Press: Washington, DC, USA, 2005.

4. Tzoulas, K.; Korpela, K.; Venn, S.; Yli-Pelkonen, V.; Kaźmierczak, A.; Niemela, J.; James, P. Promoting ecosystem and human health in urban areas using Green Infrastructure: A literature review. Landsc. Urb. Plan. 2007, 81, 167-178. [CrossRef]

5. Haq, S.M.A. Urban green spaces and an integrative approach to sustainable environment. J. Environ. Prot. 2011, 2, 601-608. [CrossRef]

6. Hartig, T.; Van den Berg, A.E.; Hagerhall, C.M.; Tomalak, M.; Bauer, N.; Hansmann, R.; Waaseth, G. Health Benefits of nature experience: Psychological, social and cultural processes. In Forests, Trees and Human Health; Nilsson, K., Sangster, M., Gallis, C., Hartig, T., DeVries, S., Seeland, K., Schipperjin, J., Eds.; Springer: New York, NY, USA, 2011; pp. 127-168. [CrossRef]

7. Kaplan, S. The restorative benefits of nature: Toward an integrative framework. J. Environ. Psychol. 1995, 15, 169-182. [CrossRef]

8. Wu, J.G. Urban ecology and sustainability: The state-of-the-science and future directions. Landsc. Urb. Plan. 2014, 125, 209-221. [CrossRef]

9. Van den Berg, M.; Wendel-Vos, W.; Van Poppel, M.; Kemper, H.; Van Mechelen, W.; Maas, J. Health benefits of green spaces in the living environment: A systematic review of epidemiological studies. Urb. For. Urb. Green. 2015, 14, 806-816. [CrossRef]

10. Wolch, J.R.; Byrne, J.; Newell, J.P. Urban green space, public health, and environmental justice: The challenge of making cities "just green enough". Landsc. Urb. Plan. 2014, 125, 234-244. [CrossRef]

11. Mahdavinejad, M.; Abedi, M. Community-oriented landscape design for sustainability in architecture and planning. Procedia Eng. 2011, 21, 337-344. [CrossRef]

12. Campbell, L.K.; Svendsen, E.S.; Sonti, N.F.; Johnson, M.L. A social assessment of urban parkland: Analyzing park use and meaning to inform management and resilience planning. Environ. Sci. Policy 2016, 62, 34-44. [CrossRef]

13. Silberberg, S.; Lorah, K.; Disbrow, R.; Muessig, A. Places in the Making: How Placemaking Builds Places and Communities; Massachusetts Institute of Technology, Department of Urban Studies and Planning: Cambridge, MA, USA, 2013.

14. Roe, M.H. The social dimensions of landscape sustainability. In Landscape and Sustainability; Benson, J.F., Roe, M.H., Eds.; E. \& F.N. Spon: London, UK, 2000; pp. 52-77.

15. Portschy, S. Community participation in sustainable urban growth, case study of Almere, the Netherlands. Pollack Period. 2016, 11, 145-155. [CrossRef]

16. Barton, H.; Grant, M.; Guise, R. Shaping Neighbourhoods for Local Health and Global Sustainability; Routledge: London, UK, 2010.

17. Derwanz, H.; Vollmer, H. Grassroots initiatives as pioneers of low-budget practices: An activists' roundtable. Ephemera 2015, 15, 229-247.

18. Bialski, P.; Derwanz, H.; Otto, B.; Vollmer, H. "Saving" the City: Collective Low-budget Organizing and Urban Practice. Ephemera 2015, 15, 1-19. 
19. Färber, A. Low-budget Berlin: Towards an understanding of low-budget urbanity as assemblage. Camb. Reg. Econ. Soc. 2014, 7, 119-136. [CrossRef]

20. Petcou, C.; Petrescu, D. R-URBAN or how to co-produce a resilient city. "Saving" the city: Collective low-budget organizing and urban practice. Ephemera 2015, 15, 249-262.

21. Gasperi, D.; Pennisi, G.; Rizzati, N.; Magrefi, F.; Bazzocchi, G.; Mezzacapo, U.; Stefani, M.C.; Sanyé-Mengual, E.; Orsini, F.; Gianquinto, G. Towards regenerated and productive vacant areas through urban horticulture: Lessons from Bologna, Italy. Sustainability 2016, 8, 1347. [CrossRef]

22. Grubbauer, M. Not everything is new in DIY: Home remodelling by amateurs as urban practice. Ephemera 2015, 15, 141-162.

23. Herman, K. Practices in low-budget landscape architecture. Ephemera 2015, 15, 279-289.

24. Project for Public Spaces. Light, Quick and Cheap: 5 Peacemaking Projects that Inspire Us. Available online: www.pps.org (accessed on 18 February 2016).

25. Soleri, P. The Frugal City. New Perspect. Q. 2013, 30, 5-10. [CrossRef]

26. Loures, L.; Loures, A.; Nunes, J.; Panagopoulos, T. The green revolution-Converting post-industrial sites into urban parks-A case study analysis. Int. J. Energy Environ. 2015, 9, 262-266.

27. Pediaditi, K.; Wehrmeyer, W.; Chenoweth, J. Monitoring sustainability of brownfield redevelopment projects-The Redevelopment Assessment Framework. Land Contam. Reclam. 2005, 13, 173-183. [CrossRef]

28. Doick, K.; Sellers, G.; Hutchings, T.; Moffat, J. Brownfield sites turned green: Realizing sustainability in urban revival. WIT Trans. Ecol. Environ. 2006, 94, 131-140.

29. Høiem, O.W. Use of Cradle to Cradle Design in Landscape Architecture. Master Thesis, Norwegian University of Life Sciences, Oslo, Norway, 15 December 2015.

30. Ziehl, M.; Oßwald, S. Practices in second hand spaces: Producing value from vacancy. Ephemera 2015, 15, 263-277.

31. Haydn, F.; Temel, R. Temporary Urban Spaces: Concepts for the Use of City Spaces; Birkhäuser: Basel, Switzerland, 2006.

32. Sung, K.; Cooper, T.; Kettley, S. Individual Upcycling Practice: Exploring the Possible Determinants of Upcycling Based on a Literature Review. In Proceedings of the Sustainable Innovation Conference, Copenhagen, Denmark, 3-4 November 2014.

33. Sung, K. Sustainable Production and Consumption by Upcycling: Understanding and Scaling-Up Niche Environmentally Significant Behaviour. PhD Thesis, Nottingham Trent University, Nottingham, UK, May 2017.

34. Szaky, T. Outsmart Waste; Berrett-Koehler Publisher Inc.: San Francisco, CA, USA, 2014.

35. McDonough, W.; Braungart, M. The Upcycle: Beyond Sustainability_Designing for Abundance; North Point Press: New York, NY, USA, 2013.

36. Yin, R. Case Study Research: Design and Methods; Sage Publications: London, UK, 1994.

37. Francis, M. A case study method for landscape architecture. Landsc. J. 2001, 20, 15-29. [CrossRef]

38. Loures, L.; Panagopoulos, T.; Nunes, J.; Viegas, A. Learning from practice: Using case-study research towards post-industrial landscape redevelopment theory. WIT Trans. Ecol. Environ. 2012, 167, $23-32$.

39. Municipality of Faro. Available online: http://www.cm-faro.pt/ (accessed on 18 October 2017).

40. Panagopoulos, T.; Duque, J.A.G.; Dan, B.M. Urban planning with respect to environmental quality and human well-being. Environ. Pollut. 2016, 208, 137-144. [CrossRef] [PubMed]

41. Zare, M.; Panagopoulos, T.; Loures, L. Simulating the impacts of future land use change on soil erosion in the Kasilian watershed, Iran. Land Use Policy 2017, 67, 558-572. [CrossRef]

42. Loures, L.; Santos, R.; Panagopoulos, T. Urban parks and sustainable city planning-The case of Portimão, Portugal. WSEAS Trans. Environ. Dev. 2007, 3, 171-180.

43. Guimarães, M.H.; Catela, L.N.; Barreira, A.P.; Panagopoulos, T. Residents' preferred policy actions for shrinking cities: A case study from Portugal. Policy Stud. 2016, 37, 254-273. [CrossRef]

44. Barreira, A.P.; Nunes, L.C.; Guimaraes, M.H.; Panagopoulos, T. Satisfied but thinking about leaving: The reasons behind residential satisfaction and residential attractiveness in shrinking Portuguese cities. Int. J. Urb. Sci. 2018. [CrossRef]

45. Berte, E.; Panagopoulos, T.; Zannon, B. An interpretative model for the management of contemporary cultural landscapes in linear infrastructure projects. J. Environ. Eng. Landsc. Manag. 2013, 21, 248-262. [CrossRef] 
46. Loures, L.; Loures, A.; Nunes, J.; Panagopoulos, T. Landscape valuation of environmental amenities throughout the application of direct and indirect methods. Sustainability 2015, 7, 794-810. [CrossRef]

47. Karanikola, P.; Panagopoulos, T.; Tampakis, S. Weekend visitors' views and perceptions at an urban national forest park of Cyprus during summertime. J. Outdoor Recreat. Tour. 2017, 17, 112-121. [CrossRef]

48. Karanikola, P.; Tampakis, S.; Panagopoulos, T.; Karipidou-Kanari, A. A perceptual study of users' expectations of urban green infrastructure in Kalamaria, municipality of Greece. Manag. Environ. Qual. 2016, 27, 568-584. [CrossRef]

49. Karanikola, P.; Panagopoulos, T.; Tampakis, S.; Tsantopoulos, G. Cycling as a smart and green mode of transport in small touristic cities. Sustainability 2018, 10, 286. [CrossRef]

50. Christopoulos, D. Towards representative expert surveys: Legitimizing the collection of expert data. In Proceedings of the Eurostat Conference for New Techniques and Technologies for Statistics, Brussels, Belgium, 34 March 2009; pp. 171-179.

51. Maestas, C. Expert Surveys as a Measurement Tool: Challenges and New Frontiers. In Oxford Handbook of Polling and Survey Methods; Oxford University Press: Oxford, UK, 2016; Available online: http:/ / www.oxfordhandbooks.com/view/10.1093/oxfordhb/9780190213299.001.0001/oxfordhb9780190213299-e-13 (accessed on 18 May 2018).

52. Ross, B.E.; Chen, D.A.; Conejos, S.; Khademi, A. Enabling adaptable buildings: Results of a preliminary expert survey. Procedia Eng. 2016, 145, 420-427. [CrossRef]

53. Corburn, J. Bringing local knowledge into environmental decision making. Improving urban planning for communities at risk. J. Plan. Educ. Res. 2003, 22, 420-433. [CrossRef]

54. Loures, L.; Panagopoulos, T.; Burley, J.B. Assessing user preferences on Brownfield regeneration. The case of Arade river waterfront, South Portugal. Environ. Plan. B Plan. Des. 2016, 43, 871-892. [CrossRef]

55. World Health Organization (WHO). Urban Green Spaces: A Brief for Action; World Health Organization, Regional Office for Europe: Copenhagen, Denmark, 2017.

56. Howitt, D.; Gramer, D. Statistics with SPSS 11 and Windows; Klidarithmos: Athens, Greece, 2003.

57. Garcia, A.; Pinheiro, R.; Marques, R.A.; Cacheira, I.R.; Pignatelli, C. Relatório Intercalar de Auditoria ao EURO/2004 No 19/2004-2a Secção; Ministry of Culture and Sports: Lisbon, Portugal, 2004.

58. Neirotti, P.; De Marco, A.; Cagliano, A.C.; Mangano, G.; Scorrano, F. Current trends in Smart City initiatives: Some stylised facts. Cities 2014, 38, 25-36. [CrossRef]

59. Berte, E.; Panagopoulos, T. Enhancing city resilience to climate change by means of ecosystem services improvement: A SWOT analysis for the city of Faro, Portugal. Int. J. Urb. Sust. Dev. 2014, 6, 241-253. [CrossRef]

60. Mohr, J. Social Design Award 2017. Ein Park Gehört Immer Allen. Interview with Martin Rein-Cano, Spiegel. Available online: http:/ / www.spiegel.de/kultur/gesellschaft/landschaftsarchitekt-martin-rein-cano-ueberstadtparks-a-1148330.html (accessed on 18 March 2018).

61. Nature-Based Solutions and Re-Naturing Cities. Available online: https://ec.europa.eu/research/ environment/index.cfm?pg=nbs (accessed on 11 May 2018).

62. Inovating Cities. Available online: http//Europa.eu/!rq76WG (accessed on 11 May 2018).

63. Lovell, S.T.; Taylor, J.R. Supplying urban ecosystem services through multifunctional green infrastructure in the United States. Landsc. Ecol. 2013, 28, 1447-1463. [CrossRef]

64. Hansen, R.; Pauleit, S. From multifunctionality to multiple ecosystem services? A conceptual framework for multifunctionality in green infrastructure planning for urban areas. AMBIO 2014, 43, 516-529. [CrossRef] [PubMed]

65. Colding, J.; Barthel, S. The potential of "Urban Green Commons" in the resilience building of cities. Ecol. Econ. 2013, 86, 156-166. [CrossRef]

(C) 2018 by the authors. Licensee MDPI, Basel, Switzerland. This article is an open access article distributed under the terms and conditions of the Creative Commons Attribution (CC BY) license (http:/ / creativecommons.org/licenses/by/4.0/). 